\title{
Damage by Tomentosus root rot in white spruce plantations in Ontario, and the effects of thinning on the disease
}

\author{
by R.D. Whitney
}

\begin{abstract}
Mortality caused by Inonotus tomentosus (Fr.) Teng (Tomentosus root rot) to dominant and codominant trees was found in all but one of 17 white spruce (Picea glauca [Moench] Voss) plantations 43-58 years old. Even though mortality usually commences at 30-35 years, younger trees can be killed. An average of $0.7 \%$ of white spruce were killed annually over the 6-year study period.

Average accumulated mortality of dominant and codominant trees was $10.3 \%$ for all plantations. Butt cull in remaining living trees averaged $13.8 \%$ of gross merchantable volume in two plots that had been clearcut at Searchmont, Ontario. Observations of the stumps of clearcut trees at Searchmont revealed that $56 \%$ of the trees had been infected. At Petawawa, Ontario, significantly higher proportions of trees were killed by I. tomentosus, and there were higher numbers of sporophores of this fungus in unthinned than in heavily thinned plantations. Tomentosus root rot also killed trees in 35- to 60-year-old plantations of black spruce ( $P$. mariana [Mill.] B.S.P.), red spruce ( $P$. rubens Sarg.) and Norway spruce (P. abies [L.] Karst.). Circumstantial evidence is presented that indicates Tomentosus root rot was introduced into plantations as I. tomentosus basidiospores.
\end{abstract}

La mortalité causée par Inonotus tomentosus (Fr.) Teng (carie rouge alvéolaire du pied) chez des arbres dominants et codominants a été observée dans 16 plantations (sur 17) d'épinettes blanches (Picea glauca ([Moench] Voss), âgées de 43 à 58 ans. Bien que l'on note généralement les cas de mortalité à partir de la plage de 30 à 35 ans, des arbres plus jeunes peuvent être tués. En moyenne, $0.7 \%$ des épinettes blanches ont été tuées pendant la période de 6 ans de l'étude.

Le taux moyen global de mortalité pour les espèces d'arbres dominantes et codominantes était légèrement supérieur à 10\% dans toutes les plantations. Le bois de rebut du pied constituait $13,8 \%$ supplémentaires du volume brut commercialisable dans deux parcelles de Searchmont, en Ontario, où il y avait eu coupe à blanc. L'inspection des souches d'arbres de coupes à blanc à Searchmont a révélé que $56 \%$ des arbres avaient été infectés. À Petawawa, en Ontario, un nombre significativement plus élevé d'arbres de plantations ont été tués par I. tomentosus, et il y avait un nombre plus élevé de sporophores de ce champignon dans les plantations non éclaircie que dans celles fortement éclaircies. La carie rouge alvéolaire du pied a également tué des arbres de 35 à 60 ans dans des plantations d'épinettes noires $(P$. mariana [Mill.] B.S.P.), d'épinettes rouges (P. rubens Sarg.) et d'épinettes de Norvège ( $P$. abies [L.] Karst.). Des preuves indirectes sont données, qui montrent que la carie rouge alvéolaire du pied été introduite dans les plantations sous forme de basidiospores d'I. tomentosus.

\section{Introduction}

Most commercially important conifers in Canada are attacked by Inonotus tomentosus (Fr.) Teng (Whitney 1978a). This fungus produces a white pocket rot commonly known as Tomentosus root rot in both roots and butts of naturally seeded and planted trees (Whitney 1977). White spruce (Picea glauca [Moench] Voss) and black spruce ( $P$. mariana [Mill.] B.S.P.), two of the main plantation species in Ontario (Anon. 1988), were found to be the two most susceptible species during an inoculation test in Saskatchewan (Whitney 1964). High losses to root rot, due in large part to I. tomentosus, have been reported in white spruce plantations at Grand Mère, Québec (Lachance 1978). Tree mortality and windthrow due to this disease have been found in several Ontario white spruce plantations (Sippell et al. 1965, 1971). Tomentosus root rot has interfered with planted white spruce in silvicultural experiments at the Petawawa National Forestry Institute in Ontario (Stiell 1986). Mortality in groups of two or three trees usually occurs at about age 30-35 years (Whitney 1977).

To further define the extent and nature of damage by this root-rotting fungus, an evaluation of mortality in 30 - to 65 -year-old white spruce plantations was conducted in Ontario between 1975 and 1989. The effect of thinning on the root rot was also investigated.

Forestry Canada, Ontario Region, Great Lakes Forestry Centre, Sault Ste. Marie, Ontario, P6A 5M7.

\section{Materials and Methods}

Fifteen white spruce plantations in Ontario, 11 at Petawawa and one plantation each at Searchmont, Thessalon, Durham and Minden, were examined. From one to nine sample plots (0.05-0.1 ha) were examined in each plantation, and were located so as to represent the stand. For example, two of the four permanent plots established in 1975 at Searchmont were in the generally diseased portion of the 253-ha plantation (about half of the plantation). In this (lower) portion of the plantation, a 0.2 -ha plot could not be delineated without encompassing several to many root-rotted (dead) trees. The other two plots were located in the upper portion of the stand, which was generally devoid of diseased trees. Neither plot contained trees killed by Tomentosus root rot at the time of establishment. Reasons for the difference between the upper and lower plots were not determined. The two stump plots at Searchmont were established after logging in 1989 in the upper portion of the stand, which was generally devoid of root rot in 1975. At Petawawa, the abundance of Tomentosus root rot was ascertained in growth and yield plots established by Stiell (1980a,b) and Berry (1974). At the time of plot establishment, Tomentosus root rot was not known to be present in the stands. Light, medium or heavy thinnings to 140,110 and $80 \mathrm{~m}^{2} /$ ha of basal area, respectively, had been conducted in 28 plots as a part of three major thinning experiments. Thinning began in 1958 , when the stands were about 35 years old, and was repeated at 10-year intervals 
until 1978. It was accomplished by removing alternate rows, thinning from below or thinning from above.

Roots of dead or chlorotic trees suspected of being killed or attacked by $I$. tomentosus were incised with an axe. The presence of white pocket decay or red stain, later culturally determined to be caused by $I$. tomentosus, implicated this fungus as a causal agent in tree decline or death. Volumes of wood lost in dead trees were computed from tree diameters and merchantable heights, and by applying Table 8 of the Ontario Manual of Scaling Instructions (Anon. 1985) for diseased living trees. The percentage of trees infected was based on those dead or chlorotic dominant or codominant trees that were infected by I. tomentosus, plus stumps of thinned or windfallen trees that were confirmed as having this decay. Evaluations were further confirmed by the presence of $I$. tomentosus sporophores around stumps or trees during September or October, the time of year when this annual fungus is visible. Sporophores were counted annually in all plots at Petawawa from 1986 to 1988 inclusive.

In addition to the main study, mortality due to Tomentosus root rot and fruiting of the causal fungus in 35- to 60-yearold plantations were observed in the following species: black spruce, three plantations at Petawawa and one at Thunder Bay; red spruce (Picea rubens Sarg.) and Norway spruce (P. abies [L.] Karst.), two plantations each at Petawawa.

\section{Results}

Tomentosus root rot was present and killed trees in the sample plots in all but one of the 17 plantations (Table 1). The typical reddish brown stain and white pocket decay (Whitney 1977) were present in killed roots and the lower bole of dead trees, and in the few living excised trees (Figs. 1 and 2). The initial observed mortality, which would have accumulated over the 5-10 years before the first observation (1981 in most instances), varied from 0.0 to $20.4 \%$ of dominant and codominant trees (Table 1). Current mortality varied from 0.0 to $8.0 \%$ of crop trees during the most recent 2-year period (1986-1987) in which data were taken. The average initial mortality in the sampled stands was $5.6 \%$ of crop trees, and the current overall average annual mortality for the period after initial measurement (1981-1987 in most instances) was $0.6 \%$.

\section{Stump Survey}

From observations of freshly cut stump surfaces in two plots at Searchmont, 59 and $54 \%$ of plantation trees were infected with I. tomentosus (Table 2). Decay seen on the stumps consisted of usually irregular central patches of discolored wood averaging 66 and $62 \%$ of the stump surface areas in infected trees in the two plots (Table 2). This decay consisted of a central zone of advanced white-pocket or yellow-pocket decay surrounded by reddish brown (or purplish) stain, or incipient decay. When $100 \%$ of the stump surface was decayed or stained and the bark was dark brown and dry, the tree was considered to have been dead before it was felled. Some trees had been felled by the wind before harvesting.

If stained wood was not acceptable, about $34 \%$ of the average butt log would be culled during scaling due to the combination of advanced decay and stain in the two stump plots at Searchmont (Table 3). The butt log makes up approximately $40 \%$ of the merchantable volume of these trees, so

Table 1. Mortality of 43- to 58-year-old semimature white spruce caused by Tomentosus root rot on 0.08- (Petawawa) to 0.2 -ha plots in 17 southern and eastern Ontario plantations.

\begin{tabular}{|c|c|c|c|c|c|c|c|c|}
\hline \multirow[b]{2}{*}{ Location } & \multirow[b]{2}{*}{$\begin{array}{l}\text { No. } \\
\text { plots }\end{array}$} & \multirow[b]{2}{*}{ Age $^{2}$} & \multirow{2}{*}{$\begin{array}{c}\text { Density } \\
\text { (trees } \\
\text { per ha })^{2}\end{array}$} & \multicolumn{5}{|c|}{$\begin{array}{l}\text { Trees killed by Tomentosus root rot }(\%)^{1} \\
\text { (based on } 110 \text { to } 675 \text { trees per plot) }\end{array}$} \\
\hline & & & & $\begin{array}{c}\text { Initial } \\
\text { examination }\end{array}$ & $\begin{array}{l}2 \text { yr } \\
\text { later }\end{array}$ & $\begin{array}{l}4 \mathrm{yr} \\
\text { later }\end{array}$ & $\begin{array}{l}6 \text { yr } \\
\text { later }\end{array}$ & $\begin{array}{l}\text { Annual } \\
\text { avg. }{ }^{3}\end{array}$ \\
\hline Durham & 1 & $53^{4}$ & $2,900^{4}$ & $0.2^{4}$ & - & 3,3 & - & 0.8 \\
\hline Minden & 1 & $44^{4}$ & $1,600^{4}$ & $0.9^{4}$ & - & 0.9 & - & 0.2 \\
\hline \multicolumn{9}{|l|}{ Petawawa } \\
\hline Hudson (3a) & 1 & 53 & 5,500 & 9.9 & 2.0 & 1.5 & 0.5 & 0.7 \\
\hline Branstead (6) & 4 & 58 & 1,700 & 2.2 & 4.2 & 0.0 & 0.8 & 0.8 \\
\hline Headquarters (12) & 9 & 57 & 1,400 & 2.9 & 1.6 & 0.6 & 0.4 & 0.4 \\
\hline Woermke (14A) & 1 & 57 & 3,000 & 5.1 & - & 0.0 & 8.0 & 1.3 \\
\hline Woermke (16) & 1 & 57 & 4,400 & 10.8 & - & 0.0 & 1.1 & 0.2 \\
\hline Halliday (20) & 2 & 56 & 2,400 & 1.0 & 1.1 & 0.0 & 1.1 & 0.4 \\
\hline Halliday (31) & 1 & 48 & 2,450 & 0.0 & 0.0 & 0.0 & 0.0 & $0.0^{5}$ \\
\hline Hudson (37A) & 2 & 48 & 2,200 & 12.0 & 1.6 & 1.7 & 2.3 & 0.9 \\
\hline Hudson (37B) & 3 & 48 & 1,800 & 20.4 & 3.2 & 1.8 & 5.0 & 1.7 \\
\hline Hudson (37C) & 2 & 48 & 1,800 & 8.5 & 0.4 & 0.8 & 1.2 & 0.4 \\
\hline Woermke (42) & 1 & 43 & 3,300 & 6.1 & - & 0.0 & 0.8 & 0.1 \\
\hline Branstead (67D) & 1 & 48 & 2,600 & 4.7 & 1.6 & 1.2 & 1.2 & 0.7 \\
\hline Lost (126) & 8 & 47 & 2,950 & 4.7 & 2.6 & 0.4 & 2.1 & 0.9 \\
\hline Thessalon & 2 & 54 & 1,600 & $0.9^{6}$ & - & - & - & - \\
\hline Searchmont & 4 & 50 & 2,200 & $8.6^{7}$ & 2.0 & 2.4 & 2.0 & 1.1 \\
\hline Average (weighted) & - & - & - & 5.6 & 2.2 & 0.9 & 1.6 & 0.6 \\
\hline \multicolumn{4}{|c|}{ Accumulated avg. mortality (\%) } & & 10.3 & & & \\
\hline
\end{tabular}

${ }^{1}$ Some dead trees had also been infested with bark beetles.

${ }^{2}$ Recorded at the time of plot establishment, mostly 1981 .

${ }^{3}$ For the period after initial measurement only.

${ }^{4}$ In 1983.

${ }^{5}$ Sporophores and dead trees killed by 1 . tomentosus were found in the plantation about $10 \mathrm{~m}$ from the observation plot in October 1988 .

${ }^{6}$ In 1987.

${ }^{7}$ In 1975 . 


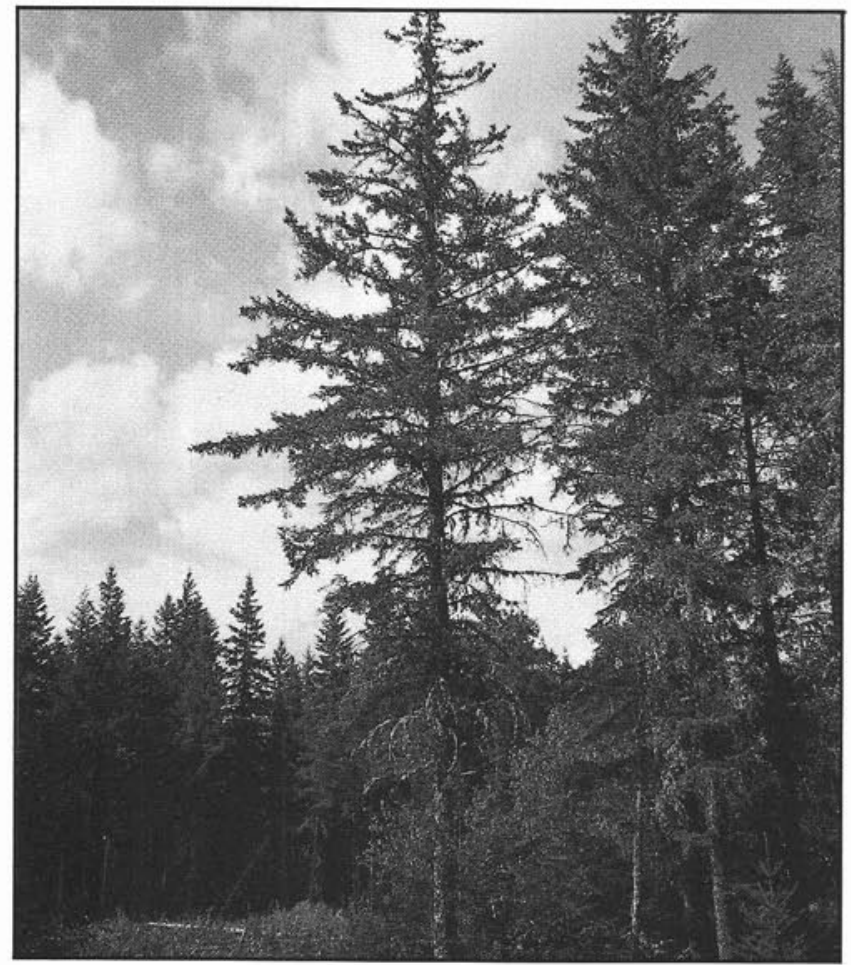

Figure 1. Planted white spruce 65 years old with thinned foliage and reduced internodes (left) as a result of heavy attack by Tomentosus root rot at Searchmont, Ontario. The tree on the right is lightly affected by the same disease.

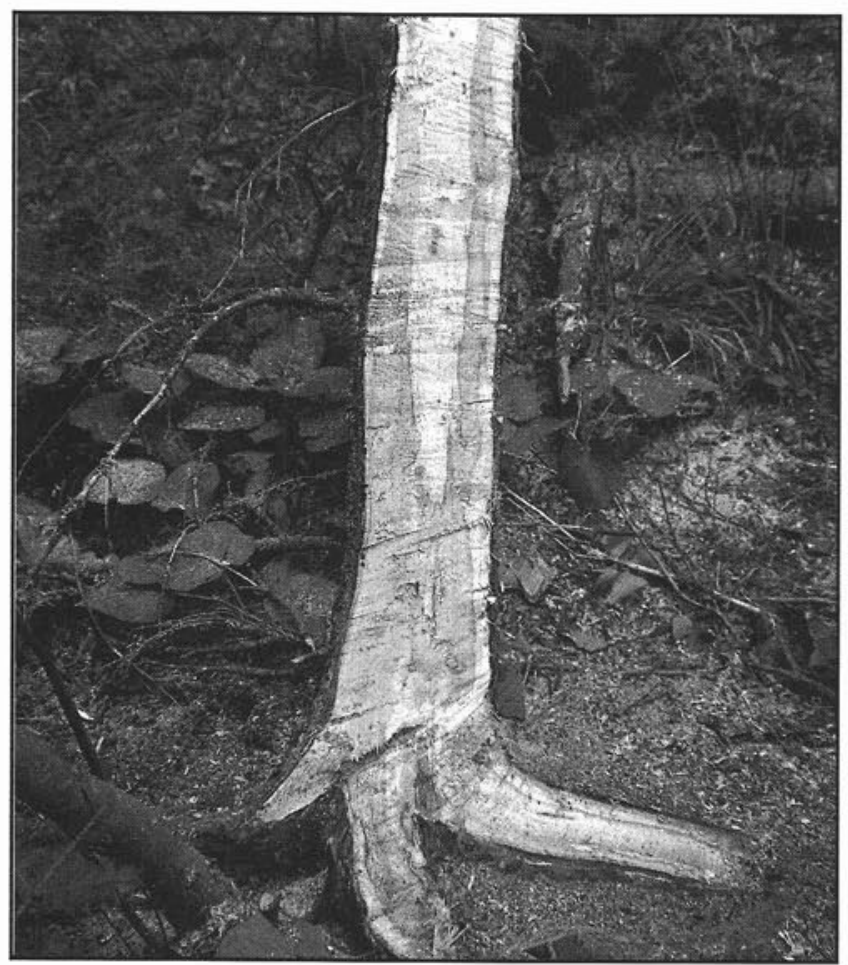

Figure 2. Heavy attack by Tomentosus root rot extending up the trunk of a living, seemingly healthy 65 -year-old planted white spruce at Searchmont, Ontario. The darkened wood is decayed or stained by Inonotus tomentosus. The root on the left was killed by this fungus.
Table 2. Proportions of trees with decay or stain caused by $I$. tomentosus in two plots of 65-year-old planted white spruce at Searchmont, Ontario.

\begin{tabular}{|c|c|c|c|c|}
\hline $\begin{array}{l}\text { Plot } \\
\text { no. }\end{array}$ & $\begin{array}{l}\text { No. } \\
\text { trees }\end{array}$ & $\begin{array}{c}\text { Infected }^{1} \\
(\%)\end{array}$ & $\begin{array}{l}\text { Proportion of stump } \\
\text { surface affected }{ }^{2} \\
(\%)\end{array}$ & $\begin{array}{c}\text { Trees } \\
\text { dead } \\
(\%)\end{array}$ \\
\hline 1 & 165 & 59 & 66 & 13 \\
\hline 2 & 144 & 54 & 62 & 24 \\
\hline
\end{tabular}

Table 3. Cull due to Tomentosus root rot in the average 2.6-m butt log in two stump plots in 65-year-old white spruce plantation at Searchmont, Ontario.

\begin{tabular}{|c|c|c|c|c|c|c|}
\hline \multirow{3}{*}{$\begin{array}{c}\text { Plot } \\
\text { no. }\end{array}$} & \multirow{3}{*}{$\begin{array}{l}\text { No. } \\
\text { trees }\end{array}$} & \multirow{3}{*}{$\begin{array}{c}\text { Butt log } \\
\text { gross } \\
\text { volume } \\
\left(\mathrm{m}^{3}\right)\end{array}$} & \multicolumn{4}{|c|}{ Scaled cull ${ }^{1}$, butt $\log$} \\
\hline & & & \multicolumn{2}{|c|}{ Decay and stain } & \multicolumn{2}{|c|}{ Decay only ${ }^{2}$} \\
\hline & & & $\mathrm{m}^{3}$ & $\%$ & $\mathrm{~m}^{3}$ & $\%$ \\
\hline 1 & 141 & 0.132 & 0.051 & 38.6 & 0.026 & 19.3 \\
\hline 2 & 105 & 0.069 & 0.017 & 29.3 & 0.009 & 14.7 \\
\hline $1 \& 2$ & 246 & 0.105 & 0.036 & 34.2 & 0.018 & 17.1 \\
\hline
\end{tabular}

${ }^{1}$ According to the Ontario Scaling Manual (Anon.1985).

${ }^{2}$ Approximately one-half of the defect was advanced decay (weakened wood unsuitable for pulping).

the average merchantable loss per tree due to decay and stain by $I$. tomentosus would be about $14 \%$. If the wood was to be used for pulp, stained wood (about $50 \%$ of the decay column) could be bleached and used, reducing the cull to $7 \%$. The narrow width of growth rings seen in heavily infected stumps during recent years was a strong indication that the growth of living infected trees had also been affected by the root rot. The volume reductions due to this reduced growth in diseased trees were not determined.

\section{Effect of Thinning}

For the three thinning intensities conducted in the white spruce plantations at Petawawa, the average accumulated mortality per plot to 1987 from Tomentosus root rot was significantly higher $(12.1 \%)$ in the unthinned (control) than in the thinned stands (Table 4). Many trees, however, were killed in thinned stands.

There were also higher numbers of $I$. tomentosus sporophores (Fig. 3) in the unthinned plots than in the heavily thinned plots (Table 4). The most valid comparison is from the 1986 sporophore counts, as this was the only year of the three (1985-1987) with an abundance of sporophores. The numbers of sporophores in a good sporophore year (1986) were well correlated with the numbers of dead trees $(r=0.885)$, and less well correlated with the degree of thinning or tree density $(r=0.510)$.

\section{Tomentosus Root Rot in Other Spruce Species}

Three to 10 dominant or codominant trees had been killed by $I$. tomentosus in each of the plantations of black spruce, red spruce and Norway spruce examined in this study. The characteristic white pocket decay was found in the roots of these trees, and cultures verified the presence of I. tomentosus in each plantation. Further evidence of the role of this fungus in the mortality was the occurrence of 9-34 sporophores around the bases of dead and diseased trees in each of the eight plantations of these species. 
Table 4. Average numbers of dominant and codominant trees killed by I. tomentosus and numbers of I. tomentosus sporophores per plot $(0.08 \mathrm{ha})$ for four levels of thinning in white spruce plantations at Petawawa, Ontario.

\begin{tabular}{|c|c|c|c|c|c|c|c|}
\hline \multirow{2}{*}{$\begin{array}{l}\text { Degree of } \\
\text { thinning }\end{array}$} & \multirow{2}{*}{$\begin{array}{l}\text { No. } \\
\text { plots }\end{array}$} & \multirow{2}{*}{$\begin{array}{l}\text { No. } \\
\text { trees }^{1}\end{array}$} & \multicolumn{2}{|c|}{$\begin{array}{c}\text { Trees killed } \\
\text { by } I . \\
\text { tomentosus }\end{array}$} & \multicolumn{3}{|c|}{$\begin{array}{l}\text { No. of } I . \text { tomentosus } \\
\text { sporophores }^{2}\end{array}$} \\
\hline & & & No. $^{2}$ & $\%$ & 1985 & 1986 & 1987 \\
\hline $\begin{array}{l}\text { Control } \\
\text { SD }\end{array}$ & 8 & 226 & $\begin{array}{l}27.4 a \\
23.6\end{array}$ & 12.1 & $\begin{array}{l}4.0 a \\
2.8\end{array}$ & $\begin{array}{l}79.4 a \\
76.9\end{array}$ & $\begin{array}{l}11.9 a \\
14.5\end{array}$ \\
\hline $\begin{array}{l}\text { Light } \\
\text { SD }\end{array}$ & 7 & 86 & $\begin{array}{l}9.0 b \\
9.4\end{array}$ & 10.5 & $\begin{array}{l}0.0 b \\
0.0\end{array}$ & $\begin{array}{l}23.1 a b \\
26.6\end{array}$ & $\begin{array}{l}8.1 a \\
20.2\end{array}$ \\
\hline $\begin{array}{l}\text { Medium } \\
\text { SD }\end{array}$ & 8 & 64 & $\begin{array}{l}5.8 b \\
6.3\end{array}$ & 9.1 & $\begin{array}{l}1.8 a b \\
2.4\end{array}$ & $\begin{array}{l}27.7 a b \\
30.0\end{array}$ & $\begin{array}{l}2.6 a \\
3.7\end{array}$ \\
\hline $\begin{array}{l}\text { Heavy } \\
\text { SD }\end{array}$ & 12 & 41 & $\begin{array}{l}1.4 b \\
1.7\end{array}$ & 3.4 & $\begin{array}{l}0.1 b \\
0.3\end{array}$ & $\begin{array}{l}8.6 b \\
14.8\end{array}$ & $\begin{array}{l}0.5 a \\
1.0\end{array}$ \\
\hline
\end{tabular}

${ }^{1}$ Average of all plots standardized to 0.08 ha.

${ }^{2}$ Values in columns with similar letters are not significantly different $(\mathrm{P}=0.05 \%)$ using ANOVA.

\section{Discussion and Conclusions}

Inonotus tomentosus killed planted white spruce trees in all plots except one (No. 31 at Petawawa) (Table 1). Even in this plantation, sporophores of $I$. tomentosus and three dead trees killed by this fungus were found about $10 \mathrm{~m}$ from the observation plot in 1988. In addition, this fungus caused mortality in black spruce, red spruce and Norway spruce plantations that were observed, but not studied in detail, during the course of the study. In the white spruce plantations, the average annual mortality rate of dominant and codominant trees for the period after initial measurement (1981-1987 in most instances) was $0.6 \%$, with the highest annual rate being $1.7 \%$ in one Petawawa plantation. Stand openings, such as those described for this disease in natural stands in Saskatchewan (Whitney 1962), occurred in some of the plantations.

Trees younger than 20 years old are not commonly killed by Tomentosus root rot. Occasional trees as young as 10 years of age have been found to be infected (Whitney and Timmer 1983). Kondo and Taylor (1984) reported that 5\% of the trees were infected in 13-to 24-year-old white spruce plantations in British Columbia. Two 19-year-old saplings were killed by $I$. tomentosus in a white spruce plantation in Saskatchewan (Whitney 1972). Based on available information, the spruces most commonly planted in Ontario are attacked by Tomentosus root rot, but mortality usually begins only after plantations reach 30-35 years of age. Significant

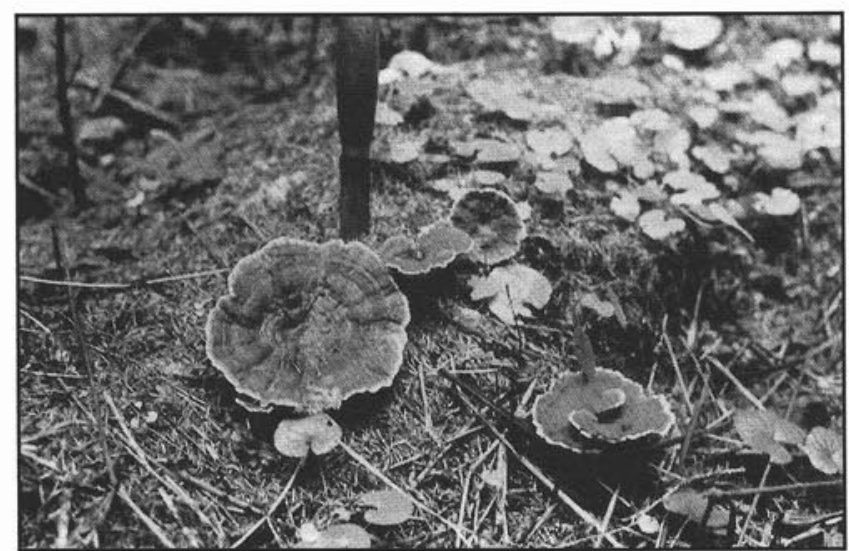

Figure 3. Inonotus tomentosus sporophores near diseased white spruce, Petawawa, Ontario (September 1986). damage occurs only after 40 years of age.

In natural stands, losses due to Tomentosus root rot occur in the form of mortality, butt cull, growth reduction and windthrow (Whitney 1977). Although mortality of dominant and codominant trees was shown to be common in plantations up to 65 years old in the present study, windthrow was minimal. Accumulated mortality due to Tomentosus root rot in dominant and codominant crown classes averaged $10.3 \%$ of trees in thinned and unthinned plantations, 50-65 years old by the end of the study. Butt cull, resulting from upward extension of the root rot into the butt of the living diseased trees, averaged $13.8 \%$ of the gross merchantable volume, as ascertained from the stump plots at Searchmont. The part of the butt cull that was only stained (about $50 \%$, equal to $7 \%$ of gross merchantable volume) could be used for pulp, but would require additional bleaching. Assuming that volumes of dead trees are equivalent to volumes of living trees of the same size, losses due to dead trees and butt cull could be $10.3 \%+13.8 \%=24.1 \%$ if dead trees or stained wood could not be utilized. If the stained wood was utilized (e.g., with additional bleaching to produce pulp), the loss would be $10.3 \%+13.8 \% / 2=17.2 \%$ of gross merchantable volume.

Added to these losses would be the increment lost due to slower growth of infected trees. The widths of current annual rings were much reduced on heavily infected trees compared with earlier growth rings; a comparable reduction was not found in uninfected trees. Killed roots and infected tissue in living infected trees interfere with the growth of the tree for many years before tree death occurs (Whitney 1962). Lachance (1978) found that sound 46-year-old planted white spruce at Grand Mère, Québec, produced $27 \%$ more wood over a 10-year period than still-living trees with butt rot caused primarily by $I$. tomentosus. Losses due to growth reduction were not calculated in the present study.

Another difficult-to-measure loss from root rot is the downgrading of the end product. The option to prolong the life of the stand for production of higher-value sawtimber is lost. Not only was the more valuable butt log defective, with decay and stain extending 2-3 $\mathrm{m}$ up the stem, but many of the infected stems would not reach sawtimber size before either dying or being windthrown. In Sweden, Arvidson (1954) concluded that root rot, from an economic standpoint, is " $\mathrm{a}$ far more serious matter than has earlier been assumed". Other European studies have shown that stumpage prices fell by as much as $23 \%$ (Rattsjo and Rennerfelt 1955) when trees were downgraded from sawtimber to pulpwood as a result of butt cull. Thus, as pointed out by Lachance (1978), "the presence of root disease in a plantation certainly deserves to be taken into account when predicting wood yields or even rotation age',

Measurements of the stumps after clearcutting revealed a high infection level by Tomentosus root rot in the Searchmont plantation. Fifty-six percent of the trees had I. tomentosus decay in the stumps and additional trees were undoubtedly infected, but the decay and stain had not yet reached stump height (Whitney 1962). Earlier studies among other tree species (Withney $1978 \mathrm{~b}$ ) revealed that only $13.7 \%$ of living white spruce in mixed natural stands were infected with I. tomentosus. In these studies, roots down to about $5 \mathrm{~cm}$ in diameter were examined and cultures were made from all stained or decayed roots. In another Ontario study, Basham and Morawski (1964) found that $13 \%$ of naturally seeded white spruce trees were infected with this fungus. 
That plantations of white spruce are more heavily attacked by this fungus than naturally seeded white spruce is further suggested by the high numbers of trees attacked in the Grand Mère plantations in Québec (Lachance 1978). Spread of the fungus from root to root, as is common with this fungus (Whitney 1962), would be facilitated to a greater extent in a pure spruce plantation than in natural stands. In natural stands, the white spruce are usually interspersed with less susceptible species such as balsam fir (Abies balsamea [L.] Mill.) or jack pine (Pinus banksiana Lamb.). Immune species such as trembling aspen (Populus tremuloides Michx.) or white birch (Betula papyrifera Marsh.) (Whitney 1964) are often present in natural stands of white spruce. Tomentosus root rot may thus be a more serious pest in pure spruce stands than in mixed stands of conifers and hardwoods.

Many of the plantations examined in the present study (e.g., Petawawa, Thessalon) were on old fields with a 40to 60-year agricultural history before tree planting. Accordingly, remains of stumps or old roots that might have served as sources of 1 . tomentosus inoculum were not found. Circumstances indicate that initial infections arose in these plantations from spores produced in nearby natural forests. Presumably, spores produced within the plantation are also active in spreading the disease once fruiting has begun (Whitney 1963).

Tomentosus root rot was reduced in thinned compared with unthinned stands at Petawawa. Both the proportion of killed trees and the number of sporophores were significantly lower in thinned plots. The discontinuity of living spruce roots is a likely reason for reduced fruiting and lower mortality in thinned than unthinned stands. Faster growth as a result of release might also provide a comparative advantage for the tree over the fungus, thus prolonging a tree's life, even if heavily infected. Similarly, new infections might be less successful in rapidly growing trees as a result of resin accumulation (Whitney and Denyer 1969).

For gravelly and coarse sandy sites, similar to Searchmont, and for fine sandy soils, similar to Petawawa, pure stands of spruce should be avoided. Native pines are also attacked by Tomentosus root rot, but to a lesser degree than spruces, and could be used on these sites. Eastern larch (Larix laricina [Du Roi] K. Koch) was as susceptible as the spruces in an inoculation test (Whitney 1964), but balsam fir is seldom attacked (Whitney 1978b). Hardwood species and cedars (Thuja spp.) are almost immune to attack by this fungus. The highly susceptible spruces should always be managed in mixed stands with less susceptible or immune species. There is no known cure for trees infected with Tomentosus root rot. If a heavy attack occurs, the stand should be harvested as soon as practical to reduce further losses (Whitney 1977). For highly valued plantings such as spruce seed orchards, removal of infected roots and stumps from the previous stand should reduce the likelihood of planted trees becoming infected.

\section{Acknowledgements}

The author wishes to acknowledge the Petawawa National Forestry Institute, and particularly Messrs. W.M. Stiell and A.B. Berry, for access to and utilization of plots and plot data. The able assistance of field technicians R. Sajan, B. Smith and R. Irwin, and of lab technician B. Britnell, is greatly appreciated.

\section{References}

Anonymous. 1985. Manual of scaling instructions. 9th ed. Ont. Min. Nat. Resour., Toronto, Ont. 112 p.
Anonymous. 1988. Statistics 1987-88 Ont. Min. Nat. Resour., Toronto, Ont. 114 p.

Arvidson, B. 1954. A study of the economic effects of root rot (Polyporus annosus) in the Norway spruce. Svensk. Skogsvard. Tidskr. 52: 381-412. (Gov't of Can., Can. For. Serv. Transl. No. 991547, 1975.)

Basham, J.T. and Z.J.R. Morawski. 1964. Cull studies, the defects and associated Basidiomycete fungi in the heartwood of living trees in the forests of Ontario. Can. Dep. For., Ottawa, Ont. Publ. 1072. 69 p.

Berry, A.B. 1974. Crown thinning a 30-year-old white spruce plantation at Petawawa -10 -year results. Dep. Environ., Can. For. Serv., Chalk River, Ont. Inf. Rep. PS-X-49. 16 p.

Kondo, E.S. and R.G. Taylor. 1984. Forest insect and disease conditions in Canada 1984. Dep. Environ., Can. For. Serv., Ottawa, Ont. 30 p.

Lachance, D. 1978. The effect of decay on growth rate in a white spruce plantation. For. Chron. 54(1): 20-23.

Rattsjo, H. and E. Rennerfelt. 1955. Losses of value in timber output as a result of butt rot. [In Swedish, with English summary.] Norrl. Skogs. Tidskr. 3: 279-298.

Sippell, W.L., B.W. Dance and A.H. Rose. 1965. Ontario Region Forest Insect and Disease Survey. pp. 58-63 In R.M. Prentice and A.G. Davidson, Ed. Annu. Rep. For. Insect and Dis. Survey, Dep. For., Ottawa, Ont.

Sippell, W.L., A.H. Rose and H.L. Gross. 1971. Ontario Region. pp. 54-72 In R.M. Prentice and A.G. Davidson, Ed. Annu. Rep. For. Insect and Dis. Survey, Dep. Environ., Can. For. Serv., Ottawa, Ont.

Stiell, W.M. 1980a. Response of white spruce plantations to three levels of thinning from below, 1958-1978. For. Chron. 56(1): 21-27. Stiell, W.M. 1980b. A row thinning experiment in white spruce plantations: 10-year progress. Rep. Exp. P-266, Study PI-12-058. Dep. Environ., Can. For. Serv. Chalk River, Ont. Typewritten MS. $26 \mathrm{p}$.

Stiell, W.M. 1986. Development of white spruce plantations at the Petawawa National Forestry Institute, Chalk River, Ont. pp. 15-20 In M. Murray Ed. The yield advantages of artificial regeneration at high latitudes. USDA For. Serv., Pacific Northwest For. Exp. Stn., Portland, Oregon. Gen. Tech. Rep. PNW-194.

Whitney, R.D. 1962. Polyporus tomentosus Fr. as a major factor in stand-opening disease of white spruce. Can. J. Bot. 40: 1631-1658. Whitney, R.D. 1963. Artificial infection of small spruce roots with Polyporus tomentosus. Phytopathology 53: 441-443.

Whitney, R.D. 1964. Inoculation of eight Saskatchewan trees with Polyporus tomentosus. Can. Dep. For., Ottawa, Ont. Bi-monthly Prog. Rep. 20(5): 3.

Whitney, R.D. 1972. Root rot in white spruce planted in areas formerly heavily attacked by Polyporus tomentosus in Saskatchewan. Dep. Environ., Can. For. Serv., Bi-monthly Res. Notes 28(4): 24.

Whitney, R.D. 1977. Polyporus tomentosus root rot of conifers. Dep. Environ., Can. For. Serv., Ottawa, Ont. For. Tech. Rep. 18. $12 \mathrm{p}$.

Whitney, R.D. 1978a. Polyporus tomentosus root and butt rot of trees in Canada. pp. 283-297 In L. Dimitri Ed., Proc. 5th Internat'l IUFRO Conf. on Problems of root and butt rot in conifers. 7-12 Aug. 1978, Kassell, Germany.

Whitney, R.D. 1978b. Root rot of spruce and balsam fir in northwestern Ontario. II. Causal fungi and site relationships. Dep. Environ., Can. For. Serv., Sault Ste. Marie, Ont. Rep. 0-X-284. $42 \mathrm{p}$.

Whitney, R.D. and W.B. Denyer. 1969. Resin as a barrier to infection of white spruce by heart rotting fungi. For. Sci. 15: 266-267.

Whitney, R.D. and V.R. Timmer. 1983. Chlorosis in planted white spruce at Limestone Lake, Ontario. Dep. Environ., Can. For. Serv., Sault Ste. Marie, Ont. Inf. Rep. 0-X-346. 16 p. 